\title{
Apocrine Glands in the Eyelid of Primates Contribute to the Ocular Host Defense
}

\author{
Mechthild Stoeckelhuber $^{\mathrm{a}}$ Beate M. Stoeckelhuber ${ }^{\mathrm{b}}$ Ulrich Welsch ${ }^{\mathrm{a}}$

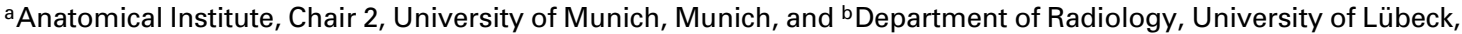 \\ Lübeck, Germany
}

\section{Key Words}

Apocrine secretion · IgA · Lysozyme · Mucin • Defensin . Marmoset monkey $\cdot$ Rhesus monkey $\cdot$ Hamadryas baboon

\begin{abstract}
Apocrine glands of Moll are regular components of primate eyelids. We studied the distribution and localization of these glands in three different primate species, the common marmoset, the rhesus monkey, and the hamadryas baboon. In addition, we tested the primate glands of Moll with antibodies against antimicrobial proteins, cytoskeletal proteins and the androgen receptor. The glands of Moll differ in abundance and distribution in different monkeys. In the common marmoset, a representative of the New World monkeys, Platyrrhini, the apocrine glands are frequently found at the lid margin and in the overlying epidermis of the lid. In the rhesus monkey and the hamadryas baboon, representatives of Old World monkeys, Catarrhini, apocrine glands are rarer and located predominantly at the margin of the lid. The immunohistochemical analysis indicates the pres-
\end{abstract}

\begin{tabular}{ll}
\hline Abbreviations used in this paper \\
\hline HE $\quad$ hematoxylin/eosin \\
SC $\quad$ secretory component \\
\hline
\end{tabular}

\begin{tabular}{ll}
\hline KARGER & ( 2004 S. Karger AG, Basel \\
1422-6405/04/1764-0187\$21.00/0 \\
$\begin{array}{l}\text { Fax +4161306 12 34 } \\
\text { E-Mail karger@karger.ch } \\
\text { www.karger.com }\end{array}$ & $\begin{array}{l}\text { Accessible online at: } \\
\text { www.karger.com/cto }\end{array}$
\end{tabular}

ence of a variety of antimicrobial proteins, e.g. lysozyme, $\beta$-defensin-2, adrenomedullin, lactoferrin, and $\lg A$, in these glands. Interestingly, there are basically no androgen receptors in the nuclei of apocrine glands at the lid margin in all three monkey species. In the common marmoset, however, androgen receptors are found in apocrine glands of the overlying epidermis of the lid. We speculate that the glands of Moll are derived from apocrine glands as found in the skin of the entire body in New World monkeys which developed at the lid margins of higher primates and humans into specialized glands secreting agents of host defense in the eye.

Copyright $\odot 2004$ S. Karger AG, Basel

\section{Introduction}

It is the aim of the present study to investigate structure and function of the apocrine glands, the glands of Moll, in the eyelids of primates with immunohistochemical and electron-microscopic methods.

Several glandular structures contribute to the tear fluid which contains among other components protective agents analyzed mainly in humans. They represent the innate immunity and are important in the defense against invasion by microorganisms. Most protective components originate in the lacrimal gland but also in conjunctival cells and the cornea. Among these agents, there are proteins or peptides such as the defensins [Haynes et al.,

Mechthild Stoeckelhuber

Institute of Anatomy, University of Munich (LMU)

Pettenkoferstrasse 11, DE-80336 Munich (Germany)

Tel. +49 8951604863 , Fax +498951604897

E-Mailmstoecke@anat.med.uni-muenchen.de 
1999; Gallo et al., 2002], the MUC proteins [Inatomi et al., 1995], lysozyme [Mason and Taylor, 1975], lactoferrin [Gilette and Allansmith, 1980], and adrenomedullin [Allaker et al., 1999]. In this context, the glands of Moll also have to be taken into consideration; so far they have been investigated in detail only in the human eyelid [Stoeckelhuber et al., 2003]. The study of these glands in different primate species, as the closest relatives of humans, gives more insight into the development and function of these glands which represent specialized ocular structures composed of apocrine glandular cells.

In all higher primates, the upper eyelids are bigger and longer than the lower lids. Both lids are sparsely covered with fine lanugo hairs, but have well-developed eyelashes arranged in two to three rows [Stewart, 1933; Rohen, 1962; Wettstein, 1963; Nowak, 1991]. The glands in the eyelid of nonhuman primates are less well studied than those of man. General histological statements indicate that both holocrine and apocrine glands are present in the eyelid of the rhesus monkey, whereas eccrine glands, as in humans, are missing [Montagna et al., 1964]. This was confirmed by Stephens et al. [1989] who described the histology of glandular components of the eyelid of the rhesus monkey in detail. In the rhesus monkey, sebaceous glands (glands of Meibom and Zeis) as well as apocrine glands (glands of Moll) are found. In addition, there are lobules of accessory lacrimal tissue (glands of Krause and Wolfring) and goblet cells. In other primates such as the common marmoset the attention was focused predominantly on the extraorbital lacrimal gland [Katsuta et al., 2000]; the glands of the eyelids have not been described. Also, in the hamadryas baboon, glandular structures of the eyelid have not been investigated so far. Ikeda [1953] compared the number of glands of Moll in human and other mammalian species and found that the glands of Moll are rarest in an unidentified monkey species of the species studied (cow, horse, pig, dog, cat, and human). The human apocrine glands of Moll in the eyelid, also called ciliary glands, obviously extrude their secretory products both by exocytosis and apocrine mechanisms [Kurosumi et al., 1984; Aumüller and Seitz, 1990; Stoeckelhuber et al., 2003] which is reflected by a variable epithelial height. The glandular tubules also contain myoepithelial cells.

The common marmoset (Callithrix jacchus) is a New World monkey (Platyrrhini) and is found in Eastern Brazil [Kavanagh, 1983; Kinzey, 1997]. The rhesus monkey (Macaca mulatta) and the hamadryas (sacred) baboon (Papio hamadryas) are members of the Old World monkeys (Catarrhini). The rhesus monkey lives in South Asia,
Indochina, and China, the hamadryas baboon in NorthEast Africa [Groves, 2001]. In evolutionary aspects the rhesus monkey and hamadryas baboon belong to the Cercopithecidae and are closer to the Hominidae (including humans) than the common marmoset [Groves, 2001].

\section{Material and Methods}

\section{Animals and Tissue}

For our investigations, we obtained monkey eyelids from the German Primate Center in Göttingen, Germany. We studied eyelids from 6 common marmosets (C. jacchus, 4 males, 2 females), 7 rhesus monkeys (M. mulatta, 3 males, 4 females), and 1 hamadryas baboon ( $P$. hamadryas, 1 male). The eyelids were fixed immediately in $4 \%$ phosphate-buffered formaldehyde for light microscopy. For transmission electron microscopy the material was fixed in $3.5 \%$ phosphate-buffered glutaraldehyde ( $\mathrm{pH} 7.2)$ and stored in $1 \%$ glutaraldehyde in the same buffer after $2 \mathrm{~h}$.

\section{Light Microscopy}

$5-\mu \mathrm{m}$ paraffin sections were stained with hematoxylin/eosin (HE) according to Romeis [1989]. Immunohistochemical staining was performed with antibodies for lysozyme (DAKO, Hamburg, Germany), secretory component (SC; DAKO) and IgA (DAKO), MUC1 (Abcam, Cambridge, UK), lactoferrin (DAKO), adrenomedullin (kindly provided by Dr. A. Martinez, Rockville, Md., USA), $\beta$-defensin-2 (kindly provided by Dr. R. Bals, Marburg, Germany), androgen receptor (DAKO), actin (ICN, Eschwege, Germany), cytokeratins CK 7 (DAKO) and CK 19 (DAKO), $\alpha$-tubulin and $\beta$-tubulin (Zytomed, Berlin, Germany). The primary antibodies were applied according to the avidin-biotin-horseradish-peroxidase complex method using the Histostain Plus Kit from Zymed (Carlton Court, San Francisco, Calif., USA) and diluted as follows: anti-lysozyme 1:1,000, anti-SC 1:200, anti-IgA 1:10, anti-mucin $11: 100$, antilactoferrin 1:200, antiadrenomedullin 1:1,000, anti- $\beta$-defensin-2 1:100 (partial slight staining of cell nuclei because of microwave pretreatment), antiactin 1:800, anti-CK 19 1:100, anti-CK 7 1:100, anti- $\alpha$ tubulin 1:200, and anti- $\beta$-tubulin 1:200. Controls, in which the primary antibody was replaced with buffer, were treated identically. Diaminobenzidine or aminoethyl carbazole were used as chromogen.

\section{Electron Microscopy}

For ultrastructural studies, eyelids were postfixed in $2 \%$ osmium tetroxide and then embedded in araldite. Thin sections were stained with uranyl acetate and lead citrate and viewed in a Philips CM 10 electron microscope.

\section{Results}

\section{General Morphology}

Apocrine glands in the eyelids of common marmoset, rhesus monkey, and hamadryas baboon are composed of glandular and myoepithelial cells. Depending on the secretory status of the cells, the height of the glandular cells 

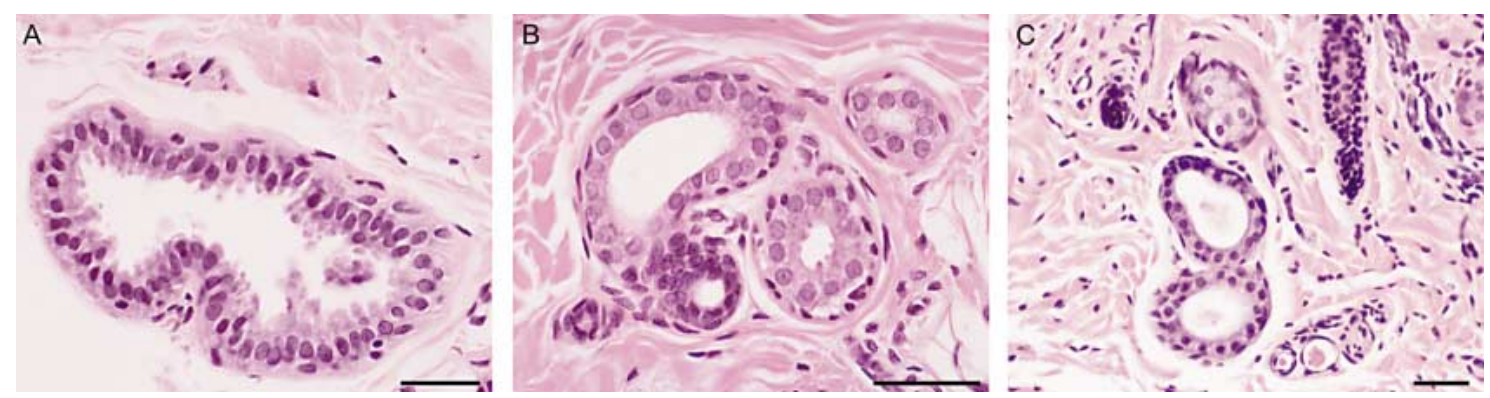

Fig. 1. Glands of Moll in the common marmoset (A) with highly active glandular cells, hamadryas baboon (B) and rhesus monkey $(\mathbf{C})$. HE stain. Scale bars $=50 \mu \mathrm{m}$.

varied from cuboidal to high prismatic (fig. 1A, B), the latter forming protrusions that are pinched off into the lumen of the gland. Myoepithelial cells are located on the basal side of the glandular cells. Apocrine glands were found at the lid margin, the so-called glands of Moll or ciliary glands, but also under the epidermis of the entire lid. Among the different species studied, the highest number of apocrine glands were found in the common marmoset with glands observed in every section at the lid. Up to 30 glandular profiles per section were counted. In the common marmoset, apocrine glands were also regularly and abundantly found in the dermis of the entire lid. In the lids of the hamadryas baboon and the rhesus monkey, apocrine glands were found predominantly at the lid margin, and very rarely under the epidermis of the lid distant from the lid margin. In addition, the number of glands were considerably reduced compared to the common marmoset. In the Old World species, we often found only one glandular profile (maximum five) in one section; many sections showed no gland at all. Only in the hamadryas baboon, could we detect some eccrine glands not at the lid margin but at some distance from the rim of the lid. These coiled eccrine glands have very small lumina. In the marmoset monkey and the rhesus monkey, we could not find any eccrine-like glands at all.

\section{Electron Microscopy}

We analyzed the ultrastructural organization of apocrine glands under the electron microscope. The ultrastructure of glands of Moll in the common marmoset, rhesus monkey, and hamadryas baboon is identical. The high prismatic glandular cells are considered to represent an actively secreting status with a round nucleus and a tall apical cell protrusion. At the apex of the cells, microvilli could be detected which were, however, absent when the protrusions were pinched off. The pinched-off blebs were devoid of organelles. In the inactive glandular cells, the

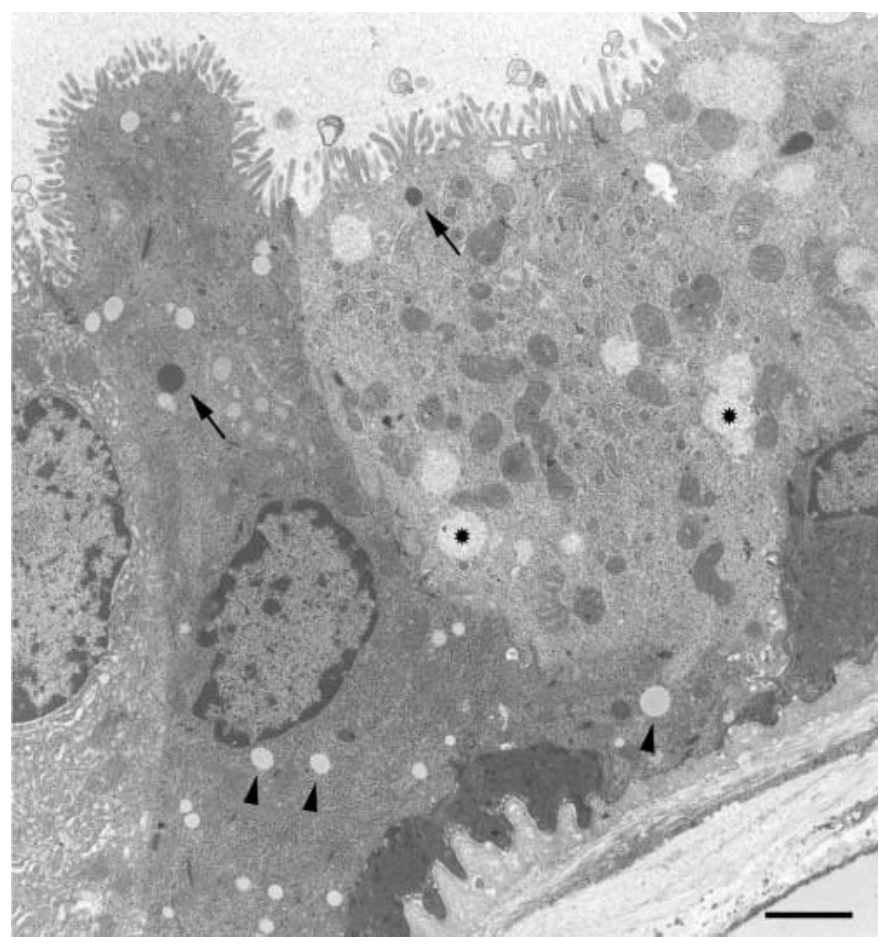

Fig. 2. Electron micrographs of active glandular cells in the common marmoset. Tall prismatic cells with numerous mitochondria and dark granules (arrows), smaller lucent lipid droplets (arrowheads), and bigger lucent granules (asterisks). Scale bar $=500 \mathrm{~nm}$.

height of the cells is reduced, and the nucleus is of irregular shape. Several membrane interdigitations especially at the basal part of the cell could be detected. The most striking structure in the cytoplasm is the great amount of mitochondria in the cells. In the cytoplasm, we found lipid droplets (diameter $0.4 \mu \mathrm{m}$ ), dark homogenous granules (diameter $0.5 \mu \mathrm{m}$ ), and paler inhomogenous granules up to $1.6 \mu \mathrm{m}$ in diameter (fig. 2). Striking features in the cytoplasm are inclusion bodies that are not lined by a membrane with densely packed and concentrically arranged 
Fig. 3. Lamellated inclusion bodies in the cytoplasm of secretory cells in the glands of Moll of a common marmoset. Note the lucent lipid droplets in the lamellated body (asterisks). Scale bar $=500 \mathrm{~nm}$.
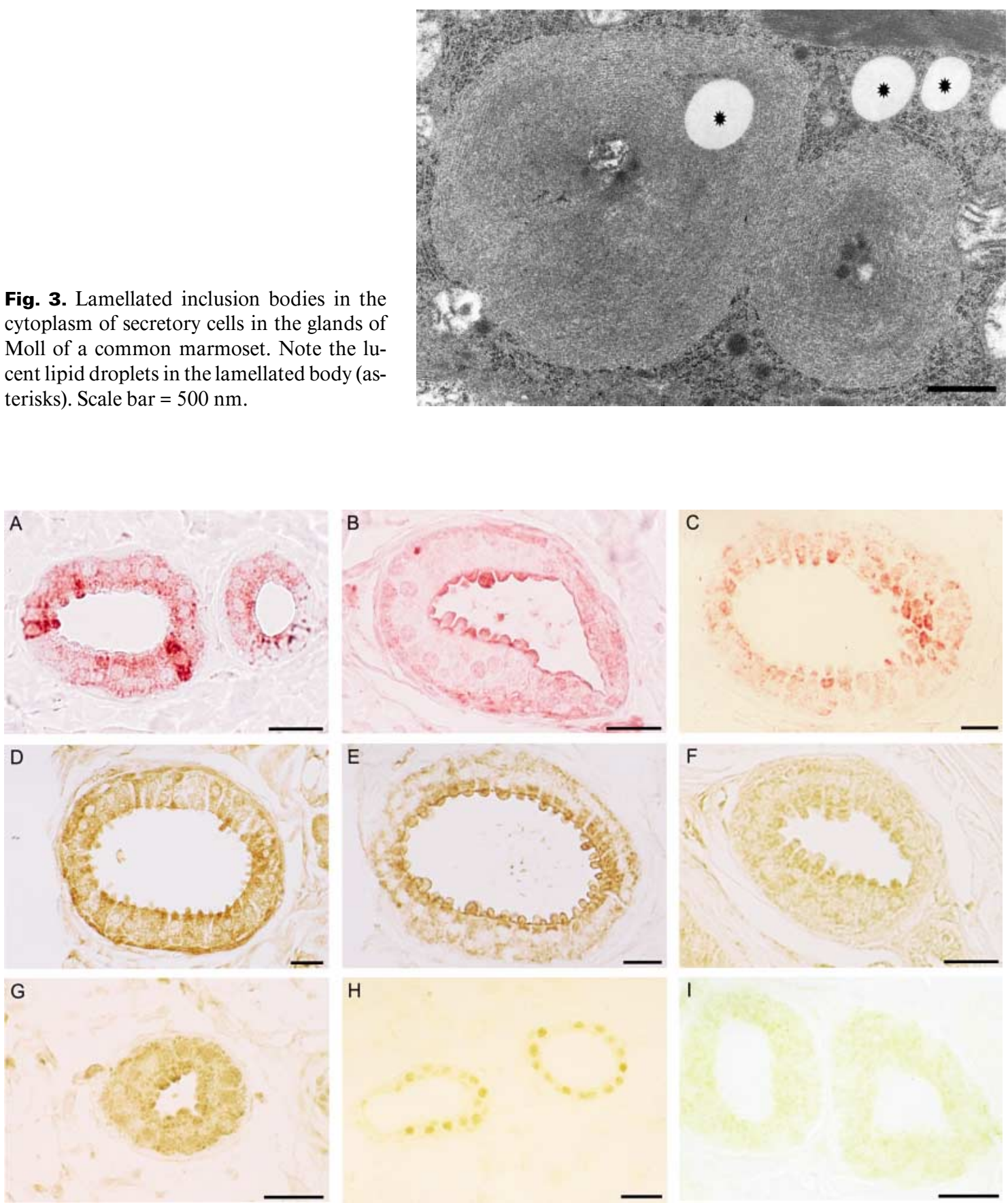

Fig. 4. Various immunohistochemical stainings in the glands of Moll of nonhuman primates. A Lysozyme staining pattern with more and less intensive expression of this protein (rhesus monkey). B $\beta$-Defensin- 2 is found predominantly in apical protrusions (hamadryas baboon). C MUC1 reactivity; the apical part of glandular cells is marked by this mucin (hamadryas baboon). D The SC of IgA occurs in variable intensity and distribution (hamadryas baboon). E IgA is expressed in the protrusions of active glandular cells (hamadryas baboon). $\mathbf{F}$ Lactoferrin is located in the whole cytoplasm with a stronger apical staining (hamadryas baboon). G The adrenomedullin stain emphasizes the cellular apices (rhesus monkey). The androgen receptor is expressed in the nuclei of glandular cells located along the overlying epidermis ( $\mathbf{H}$, common marmoset), while glandular cells along the rim of the eyelid (I) show only a granular staining of the cytoplasm (common marmoset). Scale bars $=25 \mu \mathrm{m}$. 
lamellae (fig. 3). Occasionally, these structures enclosed lipid droplets and rough endoplasmic cisterns. The rough endoplasmic reticulum is well developed in the cells, and cytoskeletal elements (intermediate filaments) are prominent. Myoepithelial cells are of a typical structure, densely packed with actin filaments. In their ultrastructure there is no difference of the glands of Moll located at the lid margin or those in other parts of the lids.

\section{Immunohistochemical Results}

Lysozyme - Common Marmoset, Rhesus Monkey, Hamadryas Baboon. This protein was expressed in distinct granules in the cytoplasm. The lysozyme pattern was variable: some glandular cells exhibited more granules than others (fig. 4A). In the apical region, the staining is more intensive (hamadryas baboon), while in active cells, the protrusions were not stained (common marmoset).

B-Defensin-2 - Common Marmoset, Rhesus Monkey, Hamadryas Baboon. Glandular cells expressed the defensin with a weak to medium intensity. In active cells, the apical part of the cell and the secreted material in the lumen were more intensively stained (fig. 4B).

Mucin 1 - Common Marmoset, Rhesus Monkey, Hamadryas Baboon. MUC1-positive granules were stained with medium intensity. Rhesus monkey, baboon: The apical part of the cells gave a stronger stain (fig. 4C). In the marmoset monkey, the apical staining was missing.

SC - Common Marmoset, Rhesus Monkey, Hamadryas Baboon. The SC of IgA showed a positive reaction in granular structures with medium intensity. The apical part of the glandular cells are strongly labeled, but in high prismatic cells, the staining of protrusions are of medium intensity (fig. 4D). In the rhesus monkey in some glandular cells the Golgi apparatus was stained.

IgA - Common Marmoset, Rhesus Monkey, Hamadryas Baboon. The granular staining pattern for $\operatorname{IgA}$ showed a weak to medium intensity. Especially the apical part of the protrusions was stained more strongly (fig. 4E). Only in the hamadryas baboon the staining was relatively weak.

Lactoferrin - Common Marmoset, Rhesus Monkey, Hamadryas Baboon. This protein is expressed in the whole cytoplasm with a medium intensity. The apical region is stained more strongly in active glandular cells (fig. 4F).

Adrenomedullin - Common Marmoset, Rhesus Monkey, Hamadryas Baboon. The staining pattern of the glandular cells showed a medium staining with a stronger mark at the apical part of the cell (fig. 4G).

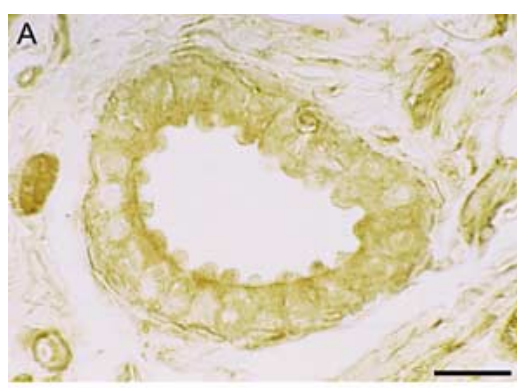

B

B

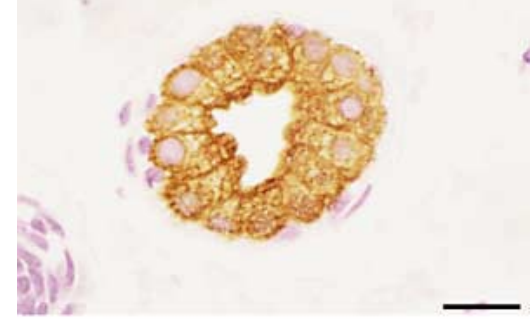

C
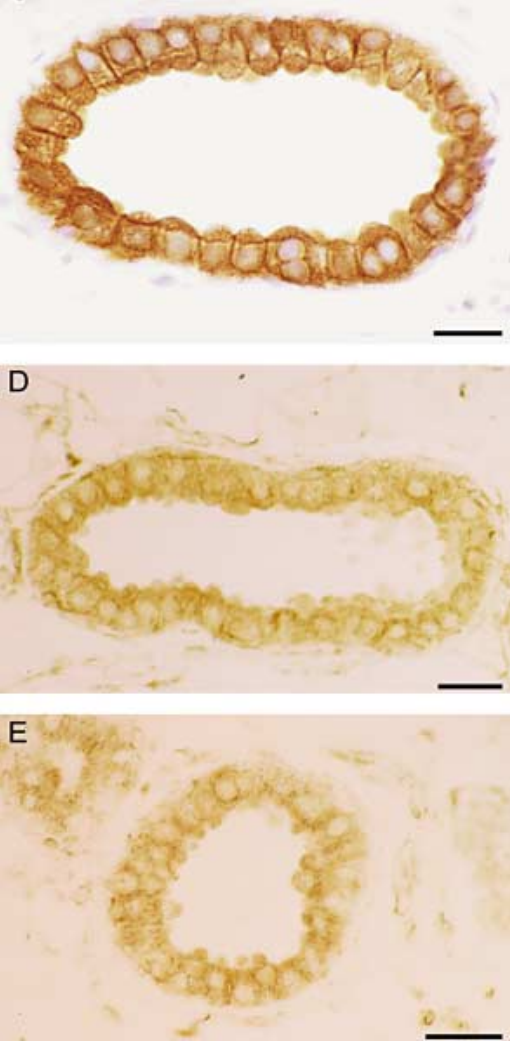

Fig. 5. Cytoskeletal components in the glands of Moll of nonhuman primates. A Actin occurs in the apical part of glandular cells; it is mainly expressed here before the pinching-off process (common marmoset). CK 7 (B, rhesus monkey) and CK 19 (C, common marmoset) show an overall staining of the cytoplasm with a slight apical accentuation. $\alpha$-Tubulin (D, common marmoset) and $\beta$-tubulin (E, common marmoset) are expressed in the whole cytoplasm. Scale bars = $25 \mu \mathrm{m}$.

Apocrine Glands in Primate Eyelids 
Table 1. Staining results of the defense proteins and the androgen receptor in apocrine glands

\begin{tabular}{|c|c|c|c|}
\hline & Common marmoset (C. jacchus) & Rhesus monkey (M. mulatta) & Hamadryas baboon ( $P$. hamadryas) \\
\hline Localization & $\begin{array}{l}\text { numerous glands at the margin of } \\
\text { the lid and along the overlying } \\
\text { epidermis }\end{array}$ & $\begin{array}{l}\text { very rare apocrine glands at the } \\
\text { lid margin and along the overlying } \\
\text { epidermis }\end{array}$ & $\begin{array}{l}\text { very rare apocrine glands at the lid } \\
\text { margin and along the overlying } \\
\text { epidermis }\end{array}$ \\
\hline $\operatorname{IgA}$ & granules in the cytoplasm $+/++$ & granules in the cytoplasm $+/++$ & granules in the cytoplasm + \\
\hline $\mathrm{SC}$ of IgA & $\begin{array}{l}\text { granules }++ \text {, apical part }+++, \\
\text { protrusions }++\end{array}$ & $\begin{array}{l}\text { granules }++ \text {, apical part }++ \\
(\text { partially Golgi apparatus }++ \text { ) }\end{array}$ & granules $+/++$, apical part +++ \\
\hline Lysozyme & granules $+/++$, protrusions - & granules $+/++$ & granules $+/++$, apical part +++ \\
\hline Mucin 1 & granules ++ & granules ++ , apical part +++ & granules ++ , apical part +++ \\
\hline$\beta$-Defensin-2 & $+/++$, apical part ++ & $+/++$, apical part ++ & $+/++$, apical part ++ \\
\hline Lactoferrin & ++ , apical part +++ & ++ , apical part +++ & ++ , apical part +++ \\
\hline Adrenomedullin &,++ apical part +++ &,++ apical part +++ &,++ apical part +++ \\
\hline Androgen receptor & $\begin{array}{l}\text { glands at the lid margin }- \text {, glands } \\
\text { along the epidermis with positive } \\
\text { nuclei }++\end{array}$ & positive nuclei -/+ & - \\
\hline
\end{tabular}

- = Negative staining; + = weak staining; ++ = medium staining; +++ = strong staining.

Androgen Receptor. In the common marmoset, a positive nuclear reaction was detected in all glands (fig. $4 \mathrm{H}$ ) except in glands that are located at the margin of the lid (fig. 4I). In the hamadryas baboon the nuclei were not stained, while in the rhesus monkey, in few cells a weak reaction of the nuclei was observed.

Actin - Common Marmoset, Rhesus Monkey, Hamadryas Baboon. Glandular cells showed a weak to medium strong staining. In the common marmoset, highly active glandular cells showed a stronger staining in the basis of the apical protrusion (fig. 5A).

CK 19/CK 7 - Common Marmoset, Rhesus Monkey, Hamadryas Baboon. The expression of these two proteins were identical in the cells. The CK 19 and CK 7 showed a medium to strong staining (fig. 5B, C). In the rhesus monkey, the apical part of the cells stained more strongly while in the common marmoset, the apical part is partially stained more strongly.

$\alpha$ - and $\beta$-Tubulins: Common Marmoset, Rhesus Monkey, Hamadryas Baboon. $\alpha$ - and $\beta$-tubulins are present in the whole cytoplasm (fig. 5D, E). The $\alpha$-tubulins showed a slightly weaker staining intensity than the $\beta$-tubulins. The staining is of medium intensity.

All histochemical and immunohistochemical results are summarized in tables 1 and 2.

\section{Discussion}

We have examined the apocrine glands of monkey eyelids with the aim to detect specific secretory products. In particular, we were interested in finding any antimicrobial factors in the apocrine glandular epithelium. The detection of IgA, the SC of IgA, lysozyme, mucin 1 , $\beta$-defensin-2, lactoferrin, and adrenomedullin in the apocrine glandular cells points to an important function of these glands in the immune defense of the eye. The staining pattern of these proteins was nearly identical in all three monkey species with some individual differences most likely depending on the secretory status of the cells. IgA, SC, lysozyme, and MUC1 are also present in the human eyelids [Stoeckelhuber et al., 2003] and are expressed identically in the apocrine glands of Moll. In humans, antimicrobial substances such as the lysozyme [Mason and Taylor, 1975], IgA, and SC of IgA [Tomasi and Grey, 1972; Fukuo et al., 1994] are secreted into the lumen of various glands. Lysozyme is localized in the lacrimal glands of man [Gilette et al., 1981]. Haeringen et al. [1975] also found low levels of lysozyme in the human conjunctiva and cornea. The MUC1 protein is a transmembrane protein that was also detected in the corneal and conjunctival epithelia of man [Inatomi et al., 1995]. 
Table 2. Staining results of the cytoskeletal proteins in apocrine glands

\begin{tabular}{|c|c|c|c|}
\hline & $\begin{array}{l}\text { Common marmoset } \\
\text { (C. jacchus) }\end{array}$ & $\begin{array}{l}\text { Rhesus monkey } \\
\text { (M. mulatta) }\end{array}$ & $\begin{array}{l}\text { Hamadryas baboon } \\
\text { (P. hamadryas) }\end{array}$ \\
\hline Actin & cytoplasm ++, apical part +++ & cytoplasm +/++ & cytoplasm +/++ \\
\hline CK 19 & $\begin{array}{l}\text { cytoplasm }++/+++ \\
\text { partially apical part }+++\end{array}$ & $\begin{array}{l}\text { cytoplasm }++/+++, \\
\text { apical part }+++\end{array}$ & cytoplasm ++ \\
\hline CK 7 & $\begin{array}{l}\text { cytoplasm }+/++/+++ \\
\text { partially apical part }+++\end{array}$ & $\begin{array}{l}\text { cytoplasm }++/+++ \\
\text { apical part }+++\end{array}$ & $\begin{array}{l}\text { cytoplasm }++/+++ \text {, } \\
\text { apical part }+++\end{array}$ \\
\hline$\alpha$-Tubulin & cytoplasm +/++ & cytoplasm $+/++$ & cytoplasm $+/++$ \\
\hline$\beta$-Tubulin & cytoplasm ++ & cytoplasm ++ & cytoplasm ++ \\
\hline
\end{tabular}

In the human mammary gland, MUC1 may be shed from the surface of the cells [Gendler, 2001] or carried along by proteins of the cell surface membranes that are pinched off via the apocrine mechanism. Adrenomedullin is a pluripotent peptide having antibacterial and antifungal properties [Allaker et al., 1999]. It has been shown that this peptide is present in mammalian skin glands, e.g. eccrine, apocrine, holocrine glands [Martinez et al., 1997; Welsch et al., 2002]. Lactoferrin is a multifunctional member of the transferrin family and is found at the mucosal surface where it functions as a prominent component of the first line of host defense against infection and inflammation [Ward et al., 2002]. In human ocular tissue, lactoferrin is present in epithelial cells of the lacrimal gland and in neutrophils of the conjunctiva [Gilette and Allansmith, 1980]. Hence, another possible source of tear lactoferrin are the epithelial cells of apocrine glands in the eyelid, as observed in the present study. The defensin is an antibiotic peptide with activity against gram-negative bacteria. Certain subclasses of $\beta$-defensins are produced in the conjunctiva, cornea, and lacrimal gland, and subclasses of $\alpha$-defensins were detected in normal tears, in the lacrimal gland, and inflamed conjunctiva [Haynes et al., 1999; McNamara et al., 1999]. Several of the substances which were found in human ocular glands were also detected in the apocrine glands of Moll in nonhuman primates. All these substances add to the antimicrobial substances of other glands in the eyelid, like the Meibomian gland and the lacrimal gland.

There may be an explanation for the variable number of apocrine glands in the three primate species studied when we look at the distribution of eccrine and apocrine glands on the whole body surface. In the rhesus monkey, the distribution of eccrine and apocrine sweat glands over the general body skin is approximately even [Montagna et al., 1964]. In the anubis baboon, the skin has more eccrine than apocrine sweat glands all over the body [Montagna and Yun, 1962]. Apocrine glands occur mainly on the anterior surface of the chest and belly and in the perianal region. Machida and Perkins [1966] and Hanson and Montagna [1962] have shown in several New World monkeys that only apocrine sweat glands are found on the general body surface, and that poorly differentiated eccrinelike glands are found only on the palms, soles, and digits. That would explain the numerous apocrine glands in the eyelids of the common marmoset. In our opinion, these apocrine glands not only represent glands of Moll at the lid margin but also belong to the apocrine glands typical for the whole body surface. This assumption is supported by the interesting finding that in the common marmoset the androgen receptor is negative in apocrine glands located at the lid margin while glands further away from the rim of the eyelid were positive. Human glands of Moll are negative for the androgen receptor [Stoeckelhuber et al., 2003] which correlates with the fact that they are active in secretion from the onset of birth. In the Old World monkeys, like the rhesus monkey and the hamadryas baboon, the apocrine glands are dramatically lower in number than in the marmoset and comparable with those in human eyelids. Hence, we speculate that the glands of Moll are specialized apocrine glands that are derived from the common apocrine glands in the skin of the whole body in more primitive primates and became then specialized glands in higher primates and humans. From birth, the secretion of antimicrobial substances for the protection of the eye became the principal function of 
the gland. The original function of a scent-producing gland has presumably become secondary.

Interestingly, we found lamellated inclusion bodies in the glandular cells that resemble lamellated inclusion bodies in epidermis cells and in pneumocytes type II of mammals. Such lamellar ultrastructural structures represent complex lipids. In the pneumocytes type II, they contain the surfactant which consists of protein and phospholipids [Veldhuizen and Haagsman, 2000]. If the glands of Moll produce lipidic materials, these may play a role in the surface film of the cornea and supplement the secretion of the Meibomian gland. In the human glands of
Moll, however, lamellated inclusion bodies could not be found [Stoeckelhuber et al., 2003].

\section{Acknowledgments}

We are particularly grateful to Dr. P. Hofmann from the German Primate Center (Deutsches Primatenzentrum) in Göttingen for providing the primate eyelids. We thank Sabine Herzmann, Claudia Köhler, Astrid Sulz, and Sabine Tost for excellent technical assistance. This study was supported by a grant from the Friedrich-BaurStiftung in Munich.

\section{References}

Allaker, R.P., C. Zihni, S. Kapas (1999) An investigation into the antimicrobial effects of adrenomedullin on members of the skin, oral, respiratory tract and gut microflora. FEMS Immunol Med Microbiol 23: 289-293.

Aumüller, G., J. Seitz (1990) Protein secretion and secretory processes in male accessory sex glands. Int Rev Cytol 121: 127-231.

Fukuo, Y., N. Takeda, H. Hirata, T. Kato, C. Kadoi, T. Katayama, Y. Kubota (1994) Immunohistological studies of an oncocytoma. Ophthalmologica 208: 267-269.

Gallo, R.L., M. Murakami, T. Ohtake, M. Zaiou (2002) Biology and clinical relevance of naturally occurring antimicrobial peptides. J Allergy Clin Immunol 110: 823-831.

Gendler, S.J. (2001) MUC1, the renaissance molecule. J Mammary Gland Biol Neoplasia 6. 339-353.

Gilette, T.E., M.R. Allansmith (1980) Lactoferrin in human ocular tissues. Am J Ophthalmol 90: 30-37.

Gilette, T.E., J.V. Greiner, M.R. Allansmith (1981) Immunohistochemical localization of human tear lysozyme. Arch Ophthalmol 99: 298-300.

Groves, C. (2001) Primate Taxonomy. Washington, Smithonian Institution Press, p 238.

Haeringen, N.J. van, F. Ensink, E. Glasius (1975) Amylase in human tear film: Origin and characteristics, compared with salivary and urinary amylases. Exp Eye Res 21: 395-403.

Hanson, G., W. Montagna (1962) The skin of primates. XII. The skin of the owl monkey (Aotus trivirgatus). Am J Phys Anthropol 20: 421430.

Haynes, R.J., P.J. Tighe, H.S. Dua (1999) Antimicrobial defensin peptides of the human ocular surface. Br J Ophthalmol 83: 737-741.

Ikeda, M. (1953) Über die Ciliardrüsen der Säugetiere. Okajimas Folia Anat Jpn 25: 163-168.

Inatomi, T., S. Spurr-Michaud, A.A. Tisdale, I.K. Gipson (1995) Human corneal and conjunctival epithelia express MUC1 mucin. Invest Ophthalmol Vis Sci 36: 1818-1827.
Katsuta, O., M. Yamaguchi-Onozawa, K. Okazaki, T. Itoh, Y. Okaraki, M. Tsuchitani (2000) Gross and microscopic anatomy of the extraorbital lacrimal gland of the common marmoset (Callithrix jacchus). Comp Med 50: 609-612.

Kavanagh, M. (1983) A Complete Guide to Monkeys, Apes and Other Primates. London, Jonathan Cape, pp 74-77.

Kinzey, W.G. (1997) New World Primates. Ecology, Evolution, and Behaviour. New York, Aldine de Gruyter, pp 230-239.

Kurosumi, K., S. Shibasaki, T. Ito (1984) Cytology of the secretion in mammalian sweat glands. Int Rev Cytol 87: 253-329.

Machida, H., E. Perkins (1966) The skin of primates. XXX. The skin of the woolly monkey (Lagothrix lagotricha). Am J Phys Anthropol 24: 309-320.

Martinez, A., T.H. Elsasser, C. Muro-Cacho, T.W. Moody, M.J. Miller, C.J. Macri, F. Cuttitta (1997) Expression of adrenomedullin and its receptor in normal and malignant human skin: A potential pluripotent role in the integument. Endocrinology 138: 5597-5604.

Mason, D.Y., C.R. Taylor (1975) The distribution of muramidase (lysozyme) in human tissues. J Clin Pathol 28: 124-132.

McNamara, N.A., R. Van, O.S. Tuchin, S.J. Fleiszig (1999) Ocular surface epithelia express mRNA for human beta-defensin-2. Exp Eye Res 69: 483-490.

Montagna, W., J.S. Yun (1962) The skin of primates. VIII. The skin of the anubis baboon $(\mathrm{Pa}$ pio doguera). Am J Phys Anthropol 20: 131142.

Montagna, W., J.S. Yun, H. Machida (1964) The Skin of Primates. XVII. The skin of the rhesus monkey (Macaca mulatta). Am J Phys Anthropol 22: 307-320.
Nowak, R.M. (1991) Walker's Mammals of the World, ed 5. Baltimore, Johns Hopkins University Press, vol 1, pp 400-510.

Rohen, J.W. (1962) Sehorgan; in Hofer, H., A.H. Schultz, D. Starck D (eds): Primatologica, Handbook of Primatology. Basel, Karger, pp 6/ 172-6/181.

Romeis, B. (1989) Mikroskopische Technik, ed 16. Munich, Urban \& Schwarzenberg.

Stephens, L.C., T.E. Schultheiss, K.J. Vargas, D.M. Cromeens, K.N. Gray, K.K. Ang (1989) Glands of the eyelids of rhesus monkeys (Macaca mulatta). J Med Primatol 18: 383-396.

Stewart, T.D. (1933) The skin and its appendages; in Kopel, B., W.L. Straus, Jr. (eds): The Anatomy of the Rhesus Monkey (Macaca mulatta). London, Baillière, Tindall \& Cox, pp 28-35.

Stoeckelhuber, M., B.M. Stoeckelhuber, U. Welsch (2003) Histochemical and ultrastructural characterization of the glands of Moll in the human eyelid. J Invest Dermatol 121: 28-36.

Tomasi, T.B., H.M. Grey (1972) Structure and function of immunoglobulin A; in Kallos, P., B.H. Waksman, A.L. de Weck (eds): Progress in Allergy. Basel, Karger, vol 16, pp 81-213.

Veldhuizen, E.J., H.P. Haagsman (2000) Role of pulmonary surfactant components in surface film formation and dynamics. Biochim Biophys Acta 1467: 255-270.

Ward, P.P., S. Uribe-Luna, O.M. Conneely (2002) Lactoferrin and host defense. Biochem Cell Biol 80: 95-102.

Welsch, U., P. Unterberger, E. Hoefter, F. Cuttitta, A. Martinez (2002) Adrenomedullin in mammalian and human skin glands including the mammary gland. Acta Histochem 104: 65-72.

Wettstein, E.B. (1963) Variabilität, Geschlechtsunterschiede und Altersveränderungen bei Callithrix jacchus; in Becher, H., G. Hertwig (eds): Morphologisches Jahrbuch. Leipzig, Akademische Verlagsgesellschaft Geest \& Portig, vol 104/2, pp 185-271. 